\title{
Chuaria circularis from the early Mesoproterozoic Suket Shale, Vindhyan Supergroup, India: Insights from light and electron microscopy and pyrolysis-gas chromatography
}

\author{
Suryendu Dutta ${ }^{1,2,3, *}$, Michael Steiner ${ }^{2}$, Santanu Banerjee ${ }^{1}$, Bernd-Dietrich \\ Erdtmann ${ }^{2}$, Silambuchelvan Jeevankumar ${ }^{1}$ and Ulrich Mann ${ }^{3}$ \\ ${ }^{1}$ Department of Earth Sciences, Indian Institute of Technology Bombay, Powai, Mumbai 400 076, India. \\ ${ }^{2}$ Technische Universität Berlin, Sekr. Ack 14, Ackerstrasse 71-76, 13355 Berlin, Germany. \\ ${ }^{3}$ Forschungszentrum Jülich, Institut für Chemie und Dynamik der Geosphäre, Sedimentäre Systeme, \\ D-52425 Jülich, Germany. \\ *e-mail: s.dutta@fz-juelich.de
}

\begin{abstract}
Chuaria circularis (Walcott 1899) from the Suket Shale of the Vindhyan Supergroup (central India) has been reinvestigated for its morphology and chemical composition using biostatistics, electron microscopy and pyrolysis-gas chromatography. Morphology and microscopic investigations provide little clues on the specific biological affinity of Chuaria as numerous preservational artifacts seem to be incorporated. On the contrary, the predominance of $n$-aliphatic pyrolysates of presently studied Chuaria from India rather supports an algal affinity. Moreover, the reflectance of $C$. circularis can be used to obtain a comparative maturity parameter of the Precambrian sediments. The review of the age and geographical distribution of $C$. circularis constrains that this species cannot be considered as an index fossil for the Proterozoic time.
\end{abstract}

\section{Introduction}

The origin and nature of Chuaria circularis has long been a topic of debate in Precambrian paleobiology since its first recognition by Walcott (1899). Chuaria had been related to hyolithids, gastropods, brachiopod, chitinous foraminifera, medusoids, trilobite eggs or was even regarded as inorganic remains in various studies (see Hofmann 1992). Ford and Breed (1973) concluded that Chuaria was a plant, most probably being a large leiospherid acritarch. White (1928) first concluded that $C$. circularis might represent an alga. Later, this view was supported by many authors, e.g., Vidal (1974, 1976); Hofmann (1971, 1977), and Jux (1977). Due to its large size, C. circularis was placed into the Megasphaeromorphida of the Acritarcha Evitt 1963. More recent interpretation was made by Sun (1987) considering Chuaria as probable colonies of filamentous cyanobacteria comparable to the modern colonial cyanobacteria Nostoc. Steiner (1997) accepted Sun's opinion, but also proposed that the widely distributed and simply constructed morphospecies $C$. circularis may have various biological affinities, i.e., mainly prokaryotic colonies of eubacteria and chroococcal or filamentous cyanobacteria, but partly even eukaryotic algae.

In India, Jones (1909) reported carbonaceous discs from the Suket Shale of Rampura area, Neemuch district, Madhya Pradesh (figure 1) and related them to either Obolella or C. circularis. Chapman (1935) assigned the specimens to the two new genera and four new species Protobolella jonesi, Fermoria minima, F. granulosa and F. capsella. Sahni (1936) placed all of them in the

Keywords. Chuaria circularis; Mesoproterozoic; Vindhyan Supergroup; pyrolysis-gas chromatography.

J. Earth Syst. Sci. 115, No. 1, February 2006, pp. 99-112

(C) Printed in India. 


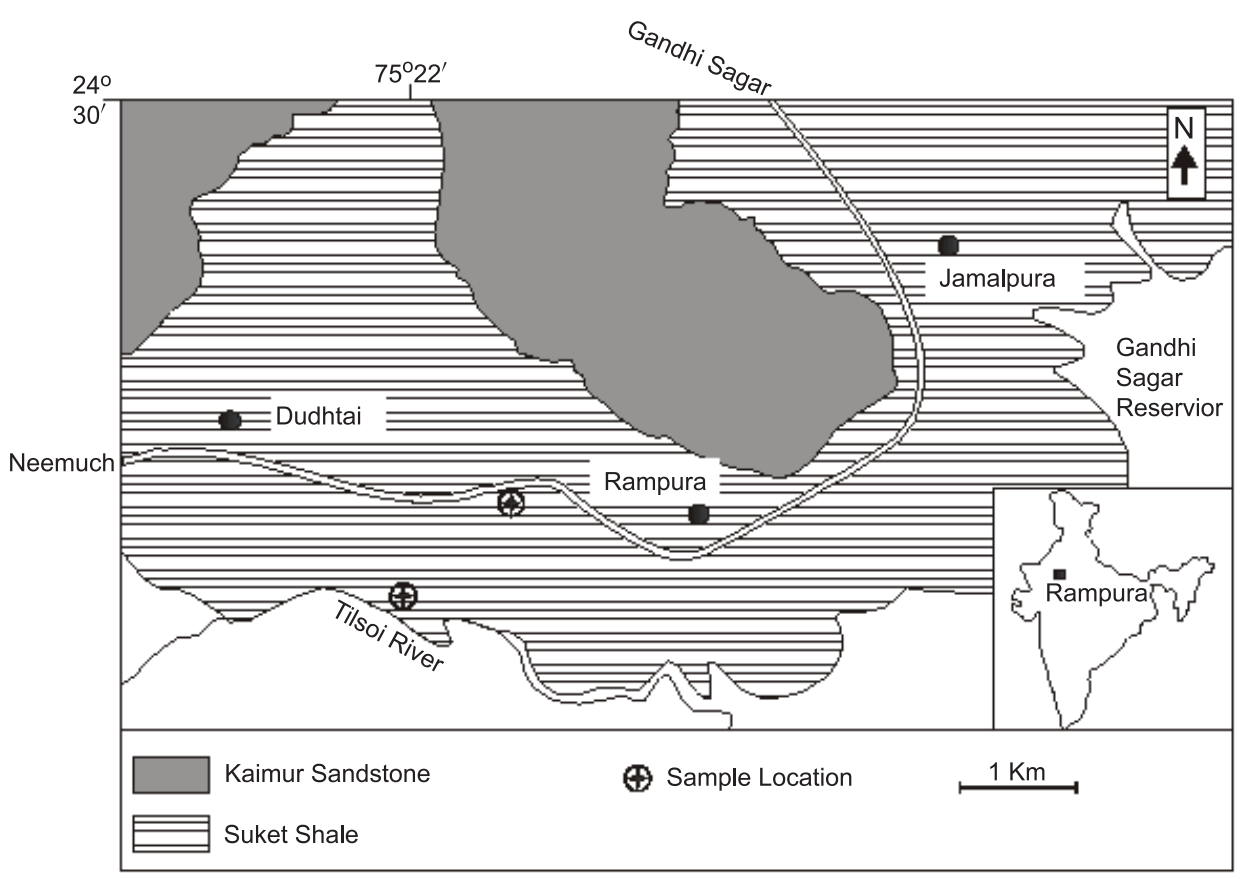

Figure 1. Geological map of the Rampura area, Neemuch district, Madhya Pradesh (after Kumar 2001) showing location of the study area (map of India within inset).

synonymy of $F$. minima, but erected the new name Vindhyanella for one of the specimens figured as Protobolella jonesi by Chapman (1935, plate 2). Maithy and Shukla (1977) suggested that the disc-like bodies are either imprints of acritarchs or algal colonies. Sahni (1977) considered the placement of Fermoria under Chuaria made by Ford and Breed (1973) an erroneous assignment. Maithy and Shukla (1984) agreed that morphologically these forms belong to Chuaria Walcott and compared them with the cryptarch genus Orygmatosphaeridium. Recently, Kumar (2001) studied the morphology of different carbonaceous fossils from the Suket Shale and considered Chuaria as a reproductive stage of a possibly cyst-like body of a Chlorophycean or Xanthophycean alga.

Molecular characterization of any Precambrian organic matter is difficult to carry out, because of its high thermal maturity. However, any structural investigation of organic matter of this age is essential in understanding evolution of Earth and life ( $\mathrm{Li}$ et al 2004). Pyrolysis-gas chromatographic study is herein reported for the first time on well-defined organic material from the Proterozoic Vindhyan sediments of India. The pyrolytic degradation has been carried out in order to obtain information on the molecular composition of the organic matter, and its potential biological origin. Accordingly, this paper presents a comprehensive study including morphology, biostatistics, SEM and TEM images and molecular composition of Chuaria from the Suket Shale of the Lower Vindhyan, Semri Group.

\section{Samples}

The Vindhyan Supergroup represents a thick (up to $4500 \mathrm{~m}$ ) succession of undeformed and slightly metamorphosed, Paleoproterozoic to Neoproterozoic sediments exposed in Rajasthan and Son valley regions. The study area is situated in the less-studied northwestern region of the Vindhyan basin.

The Vindhyan Supergroup is two-tiered and consists of the Lower Vindhyan Group (or the Semri Group) and the Upper Vindhyan Group. Vindhyan sedimentation took place largely in a shallow marine environment (Chanda and Bhattacharyya 1982), but the depositional environment fluctuated between offshore, deltaic, lagoonal, fluvial and even eolian settings (Bose et al 2001).

The Suket Shale occupies the low lying plains around Rampura (figure 1). The rocks are exposed in the Tilsoi River section, Nala cuttings and along the Rampura-Neemuch road section. The main lithologies of the Suket Shale are green shales, greyish yellow shales with subordinate occurrences of greyish black carbonaceous shales, siltstones and light brownish grey sandstones. The contact between Suket Shale and Kaimur Group is gradational. The Suket Shale is commonly correlated with the Rampur Shale in the Son valley (Sarkar et al 2002) where it consists of greyish and carbonaceous shales intervened by siltstones/fine grained sandstones. The Suket Shale of the Rampura area has not been dated so far, 
however, its stratigraphical position can be inferred from a correlation with strata in the Son valley area. Absolute ages for Vindhyan strata from the Son valley are given by Rasmussen et al (2002) who dated the tuff bands occurring at the base of the Rampur Shale and fixed an age of $1599 \pm 8 \mathrm{Ma}$ by the U/Pb method. Sarangi et al (2004) recently obtained an age of $1599 \pm 48 \mathrm{Ma}$ for the overlying Rohtas Formation containing carbonaceous fossils (Grypania) by the $\mathrm{Pb} / \mathrm{Pb}$ dating technique. On this basis the age of the Suket Shale can be estimated at roughly $1600 \mathrm{Ma}$. Samples for the present study have been collected from comparably fresh well cuttings near the Tilsoi River section and are preserved at the China Research Center (Sekr. ACK 14) of Technical University, Berlin.

\section{Methods}

For reflected light, scanning electron microscope (SEM) and transmission electron microscope (TEM) analyses, specimens of Chuaria were extracted from the rock matrix using $40 \% \mathrm{HF}$ acid (for three days). After treatment with HF the samples were neutralized using a $10 \mu \mathrm{m}$ mesh filter. Well preserved individuals of Chuaria were picked from the organic residue by a pipette. Both, isolated specimens, and those preserved in situ on the rock surfaces were studied in reflected light under a Leitz-Wild-M3Z binocular microscope.

Specimens selected for SEM were mounted on a preparation stub and coated with a $20 \mathrm{~nm}$ layer of gold and investigated by a Hitachi S520 at TU Berlin. The wall thickness of specimens of Chuaria circularis was determined by measurement of transversal fractures under SEM or by measurement of embedded and sectioned individuals using light microscopy under high magnification. Extracted specimens for the TEM analysis were dehydrated using ethanol and embedded in Araldite CY 212 resin. The ultra-thin sections (thickness $70 \mathrm{~nm}$ ) were cut perpendicular to the compressed surface of the specimens in an ULTRACUTE and placed on copper grids for study in a JEOL 200B TEM at TU Berlin.

For reflectance studies, whole rock fragments containing Chuaria as well as individuals of Chuaria isolated from the Suket Shale of India, the Visingsö Formation of Sweden and from the Liulaobei Formation of China were embedded in Araldite resin and polished by a standard coal petrographic technique (Mackowsky 1982). The percentage of random reflectance was measured in oil immersion $\left(n_{\text {oil }}=1.518\right)$ at a $546 \mathrm{~nm}$ wave length at $23^{\circ} \mathrm{C}$.
For pyrolysis, specimens of Chuaria were scratched off from the bedding planes of rock samples using a sharp scalpel and subsequently only the organic remains of Chuaria were handpicked under a stereomicroscope. Prior to chemical investigations, these organic walled fossils were cleaned several times with dichloromethane to remove free hydrocarbons.

Molecular characterisation of Chuaria was performed by open-system off-line pyrolysis method and pyrolysis products released during thermal degradation were first collected and studied at a later stage. Up to $1.0 \mathrm{mg}$ of sample was heated in a flow of helium. Pyrolysis products released over a temperature range $<300^{\circ} \mathrm{C}\left(300^{\circ} \mathrm{C}\right.$ held for 5 minutes) were vented. Products released over a temperature range from 300 to $600^{\circ} \mathrm{C}\left(50^{\circ} \mathrm{C} / \mathrm{min}\right)$ were collected in a cryogenic trap (liquid nitrogen cooling) from which they were then liberated by ballistic heating. Gas chromatographic analysis was carried out using a $50 \mathrm{~m} \times 0.31 \mathrm{~mm}$ fused silica column (HP-1; 0.5 $\mu \mathrm{m}$ film thickness) programmed from $40^{\circ} \mathrm{C}$ to $300^{\circ} \mathrm{C}$ with a heating rate of $5^{\circ} \mathrm{C}$ per minute. The relative abundance of compounds was determined using Multichrom chromatography data system (VG DATA SYSTEMS).

\section{Systematic Description}

\section{Genus: Chuaria Walcott}

\section{Species: Chuaria circularis Walcott}

(plate 1 and plate 2)

Lectotype: Ford and Breed 1973, p. 540, figure 1, USNM 33800

Synonymy: For synonymy, see Maithy and Shukla (1984), Steiner (1994), Talyzina (2000)

Type locality: Kwagunt Valley, Grand Canyon, Arizona, USA

Investigated locality: Rampura, Neemuch District, Madhya Pradesh, India

Lithology: Black shales, greyish black shales, yellow shales

Description: Circular to elliptical discs ranging in size from $0.25 \mathrm{~mm}$ to $4.75 \mathrm{~mm}$ are either preserved in the form of carbonised compressions on black/grey shale or imprints on weathered, yellow shale (plate 1a, 1b, 1c). Discs may contain concentric and irregular wrinkles resulting from the compression of originally spherical bodies (plate 1a). Rare three-dimensional specimens are occurring, probably due to infilling (plate 1d). Few specimens 

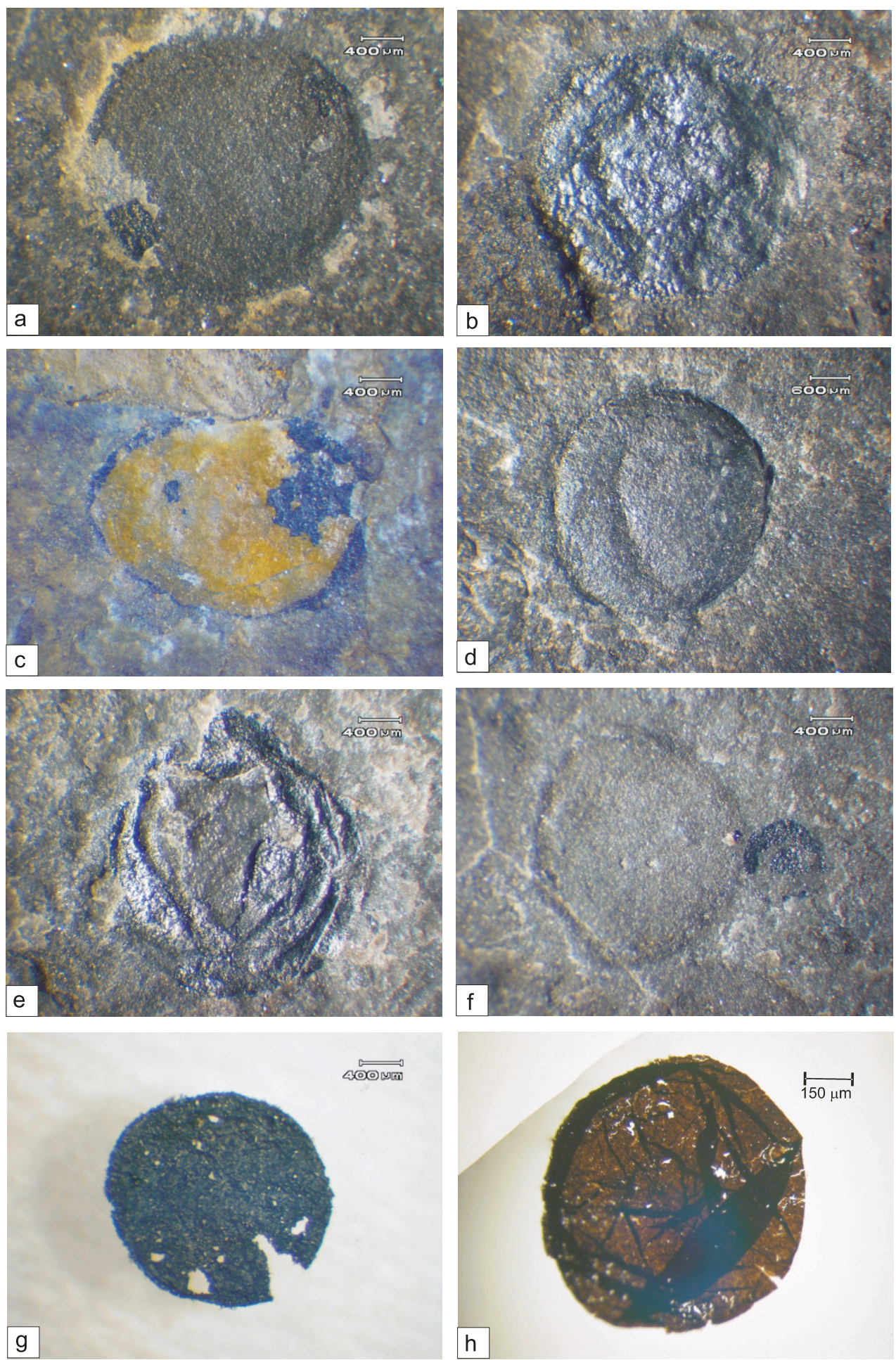

Plate 1. (a) C. circularis with wrinkles at the boundary (sample number $\mathrm{R}_{2} / 10 / 1$ ); (b) C. circularis with thick carbonaceous matter and imprints of sediment on top of it (sample number $\mathrm{R}_{2} / 4 / 2$ ); (c) C. circularis showing elliptical shape, carbonaceous matter partially weathered out (sample number $\mathrm{R}_{2} / 4 / 3$ ); (d) Three dimensionally preserved $C$. circularis (sample number $\mathrm{R}_{2} / 2 / 3$ ); (e) C. circularis with strongly folded thick carbonaceous matter (sample number $\mathrm{R}_{2} / 5 / 2$ ); (f) Attached individuals of $C$. circularis of different size and different thickness of preserved organic matter (sample number $\left.\mathrm{R}_{2} / 3 / 2\right)$; (g) C. circularis after separation from rock matrix by HF. Note that the specimen shows a compactional crack structure (referred to as 'opening structure' by other authors) and opaque, thick organic matter with sediment grain imprints. Opacity is correlated with a mostly large maximum diameter (ca. 200-4000 $\mu \mathrm{m})$ and great wall thickness $(>1000 \mathrm{~nm}) ;(\mathbf{h})$ C. circularis after separation from rock matrix by HF. Note circular and irregular folds, resulting from compaction of relatively thin organic matter. Medium brown colour is correlated with medium maximum diameter (ca. 200-2000 $\mu$ m) and a relatively thin wall thickness (ca. $350 \mathrm{~nm}$ ). All samples are derived from the Suket Shale, Vindhyan Supergroup, Rampura, Madhya Pradesh, India. Specimens are deposited at the China Research Center (Sekr. ACK 14) of TU Berlin. 

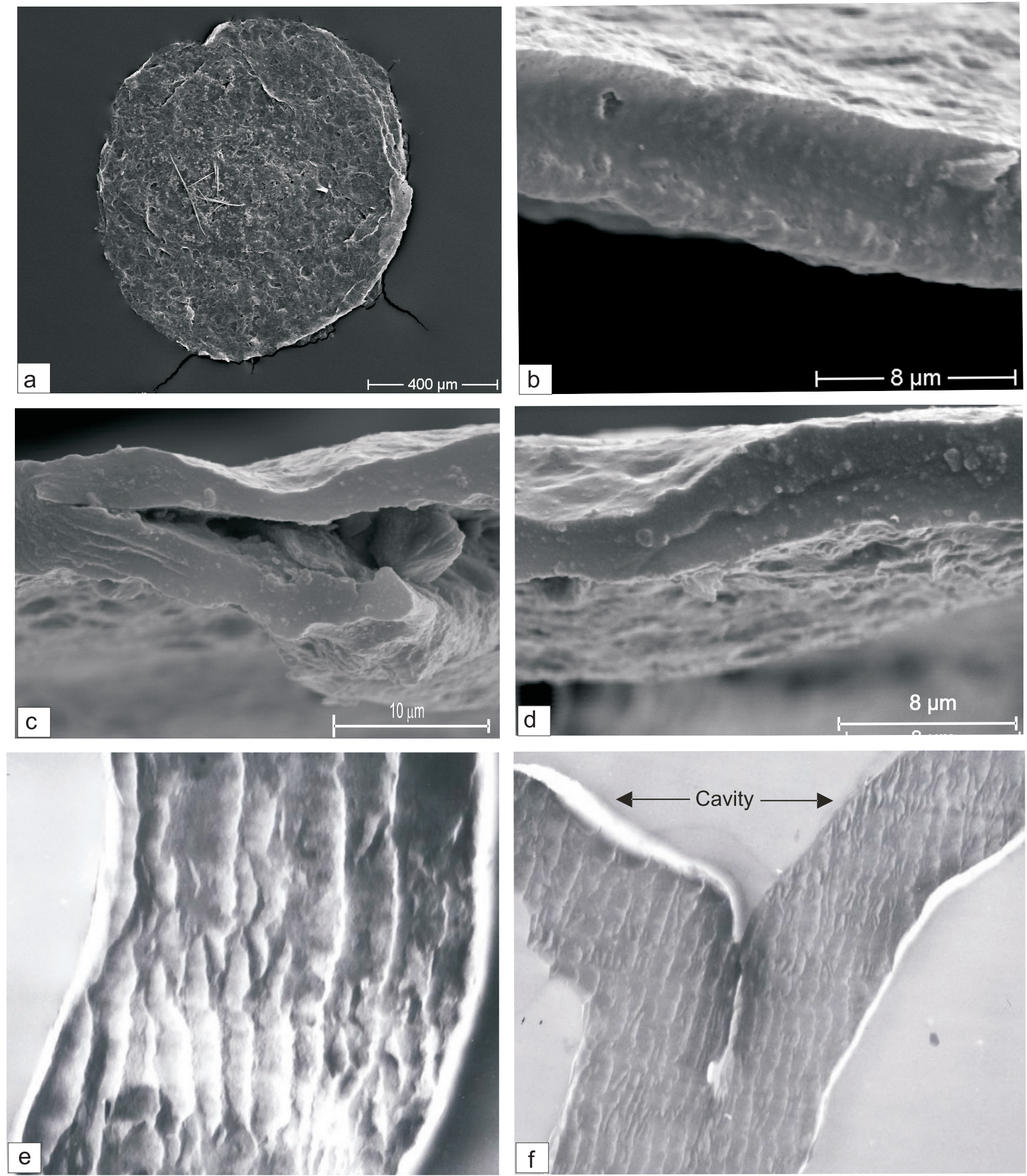

Plate 2. (a) Scanning electron micrograph of C. circularis. Note that concentric wrinkles are not well developed, but sediment grain imprints are prominent; (b) Scanning electron micrograph of transversal fracture of a specimen of $C$. circularis, indicating massive single layer without a median split; (c) Scanning electron micrograph of transversal section of a specimen of $C$. circularis with folded layer; (d) Scanning electron micrograph of transversal section of a specimen of $C$. circularis, showing an irregular cavity within the wall, but no median line as it should be expected from the compaction of a central cavity of a vesicle; (e) Transmission electron micrograph of C. circularis, showing lamellar structure (magnification $30000 \times)$; (f) Transmission electron micrograph of $C$. circularis, showing cavity within the wall (magnification $25000 \times$ ). All samples are derived from the Suket Shale, Vindhyan Supergroup, Rampura, Madhya Pradesh, India. Specimens are deposited at the China Research Center (Sekr. ACK 14) of TU Berlin. 
occur as intergrown groups (plate 1f). The surfaces of most compression have been deformed to a varying degree by sediment grains from the surrounding rock matrix during compaction (plate $1 \mathrm{~b}, 1 \mathrm{e}, 1 \mathrm{~g}$ ). Circular and irregular folds are also preserved in the specimen, isolated from rock matrix (plate $1 \mathrm{~h}$ ). Isolated specimens show yellow to dark brown colouration in transmitted light or are opaque.

\subsection{Discussion}

Difficulties in interpreting the original primary morphology and biological assignment of Chuaria circularis are derived from the fact that numerous preservational artifacts and taphonomic alterations are incorporated within this simple fossil. The species Chuaria circularis is herein regarded as a form-taxon of very simple morphology, which may embrace similar remains of different biospecies. The characters of Chuaria circularis are partly overlapping with those of several species of large leiospherid acritarchs. Species differentiation based on the presence of such characters of acids resistance, opacity and compressional fold arrangement may be practical, but are arbitrary. Therefore, acid resistance, opacity and fold arrangement are not used in taxonomical sense herein. Walcott (1899) in his original report described this species as a brachiopod showing regular ring-like wrinkles. Chuaria was later considered as spheroidal or a hollow spheroid with a narrow flange (Ford and Breed 1973). Duan (1982) believed that such concentric wrinkles are of inherent morphological features and may be diagnostic criterion and argued that the marginal flange described by Ford and Breed (1973) was originally a part of the ring-like wrinkles. Butterfield et al (1994) used the presence of concentric wrinkles as diagnostic character. Specimens of Chuaria circularis from the Suket Shale occur with marginal wrinkles (plate 1a), while others do not (plate 1g). However, similarities in their size range, composition and other characteristics seem to indicate that the concentric wrinkles are only preservational alterations caused by slightly differing modes of compaction. Variable preservation with partial lack of the often typical concentric wrinkles is also reported from an early diagenetically mineralized (pyritized) assemblage of chuarids (Yuan et al 2001). The specimens of the present study also show irregular microfolds (plate 1e) probably resulting from dewatering after deposition. Hofmann (1985a) also suggested that the folds and marks on carbonaceous megafossils are compactional artifacts. Overlapping of specimens is not common, even in dense accumulations. Therefore, Duan (1982) concluded that Chuaria was spherical in shape. Compactional cracks have been postulated as excystment structures of eukaryotic megacysts (Yuan et al 2001) or 'opening-structure' for the release of spores on maturation of Chuaria (Kumar 2001; figure 6j). However, similar cracks were produced by compaction experiments on modern spherical colonies of cyanobacteria (Steiner 1994; plate 1, figure 3). Similar structures found in the present study (plate $1 \mathrm{~g}$ ) suggest a compressional origin, which is supported by the observation of Eisenack (1966) that cracks commonly occur in the younger stages rather than in mature specimens.

\section{Colour}

Butterfield et al (1994) discussed opacity as an inherent character of Chuaria and postulated that opacity of these fossils from the Svanbergfjellet Formation is not a direct function of wall thickness, but rather dependent on histological characteristics. Therefore, translucency, wall thickness and colour of $C$. circularis are herein systematically studied. Specimens of the present study show colour variation from yellow via brown to black (opaque). Three major characters may be considered to determine the colour of any fossilised organic substance:

- thermal maturity,

- wall thickness and

- type of the material.

Specimens of the present study are collected from the same stratigraphic horizon and at the same locality but show a wide range of colours implying that thermal alteration could have played a small role only. Wall thickness of this fossil may be the reason for colour variation. To study the relationship between colour, wall thickness and size of Chuaria circularis, a number of specimens were classified according to a subjective colour scale and their size and wall thickness were recorded (figure 2). Numerous specimens of each size class and colour group were measured. A systematic trend of increasing translucency and a presence of lighter colours with smaller maximum diameters of individuals of $C$. circularis was recognized. However, dark or opaque individuals occurred also in smaller size classes, although they were less abundant than individuals larger than $500 \mu \mathrm{m}$ in diameter. Opacity occurred in Indian material from the Suket Shale at a total 'wall' thickness of about $1 \mu \mathrm{m}$ or more, while translucent individuals with brown colouration ranged from ca. 350 to $750 \mathrm{~nm}$ in total thickness (figure 2). The recorded range of total 'wall' thickness from 0.3 to $23.85 \mu \mathrm{m}$, is quite large and contradicts an interpretation as vesicle or even cell walls of only one biological species. It is obvious that with increasing 


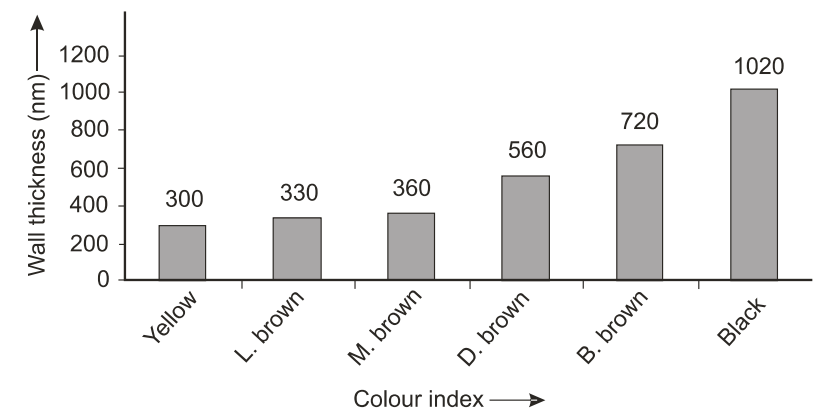

Figure 2. Variation of colour with total 'wall' thickness of Chuaria circularis, Suket Shale, Vindhyan Supergroup, India.

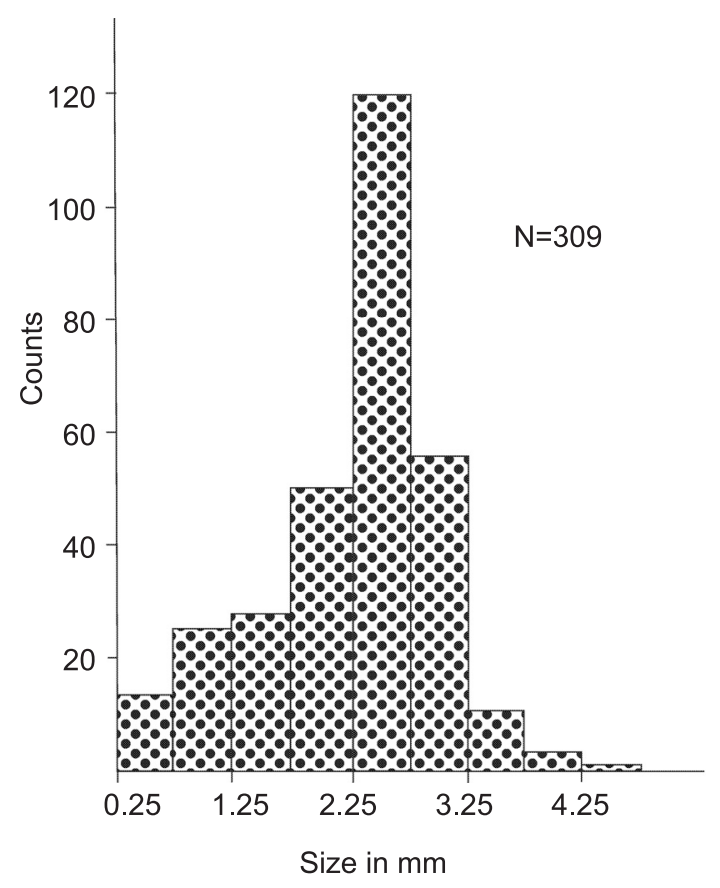

Figure 3. Size histogram of Chuaria circularis, Suket Shale, Vindhyan Supergroup, India.

'wall' thickness, the colour of Chuaria changes from yellow to brown to black (opaque). It has also been observed that large black (opaque) individuals of Chuaria became translucent (brown) in areas of corrosion. Similar conclusions were also drawn by Steiner (1994) after detailed study of $C$. circularis from the Liulaobei Formation, north China. It can be concluded that opacity is a direct function of wall thickness and thus may not be an inherent property of Chuaria. Regional differences in opacity of organic matter of Chuaria may result from differing thermal history.

\section{Biostatistics}

Size statistic of Chuaria circularis from the Suket Shale reveals a variation from $0.25 \mathrm{~mm}$ to $4.75 \mathrm{~mm}$ and a unimodal size distribution with a mode in

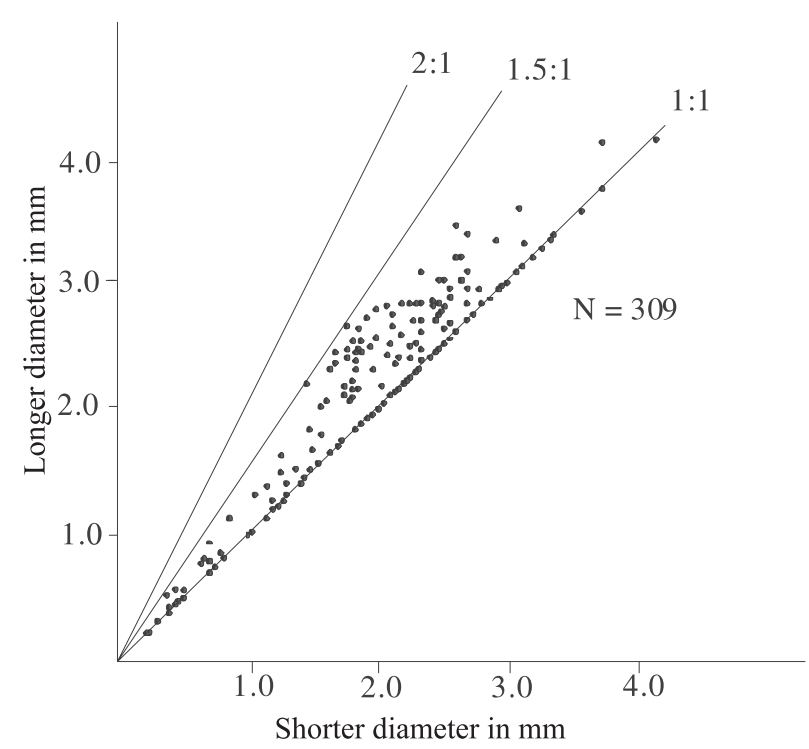

Figure 4. Scatter diagram for longer dimension plotted against shorter dimension for Chuaria circularis, Suket Shale, Vindhyan Supergroup, India.

the size range of $2.25 \mathrm{~mm}$ to $2.75 \mathrm{~mm}$ (figure 3 ). In the scatter diagram (figure 4 ) the ratio between the longer and shorter diameter varies between 1 and 1.5. Both, smaller and larger forms exhibit almost identical morphological features. Gahre and Badve (1978) and Maithy and Shukla (1984) showed a size frequency distribution of $C$. circularis from the Suket Shale and concluded that large size specimens dominate in black shales whereas the smaller size are common in yellow shales. The present study, however, reveals equal occurrences of both, larger and smaller Chuaria specimens, within the black shales (plate 1f).

The wall thickness ranges from $0.3 \mu \mathrm{m}-23.85 \mu \mathrm{m}$ for examined specimens from the Suket Shale (plate $2 \mathrm{~b}-\mathrm{d}$ ). The original description of the typespecies Chuaria Walcott from the Chuar Group (Wallcott 1899) does not provide any data on the total 'wall' thickness. However, Jux (1977) mentioned that 'wall' thickness of $C$. circularis varies from 2-2.5 $\mu \mathrm{m}$. Ford and Breed (1973) mentioned a 'wall' thickness of 50-70 $\mu \mathrm{m}$ of Chuaria from the Visingsö Formation, but Amard (1992) argued that the original wall thickness ranges from $15-30 \mu \mathrm{m}$ in these same samples. The wide range in thickness may be the result of either biodegradation or differential compaction. Recently, Javaux et al (2004) suggested that variations in wall thickness of the Proterozoic organic walled microfossils could be due to compaction.

There is not much agreement on a potential size limitation as a diagnostic feature of Chuaria. Ford and Breed (1973) mentioned C. circularis as flattened carbonaceous spheroids with wrinkles and cracks, but within a size limit of 500 to $5000 \mu \mathrm{m}$. 
Vidal (1974, 1976) did not agree with Ford and Breed (1973) in applying size limits and reported that the size range of most of his specimens remain in the range of $0.09-0.2 \mathrm{~mm}$ and few up to $3 \mathrm{~mm}$. Sun (1987) strongly recommended that Chuaria is typically characterized as macroscopic in size and mentioned that the size range should be taken as a practical, convenient criterion to distinguish Chuaria from various acritarch forms. But Steiner (1997) rejected that size limits are artificial in defining C. circularis. Kumar (2001) showed a bimodal distribution of Chuaria and on this basis he erected the new species as $C$. vindhyansis which is distinguished from Chuaria circularis by a smaller size. We do not agree with this interpretation, since both smaller and larger forms exhibit identical morphological features. In contrast to a biological interpretation, bimodality in size may indicate a sorting effect due to reworking if other characters do not differ.

\section{Ultrastructure}

SEM investigations reveal no special ornamentation on the surface of the specimens of Chuaria circularis except a few pits interpreted as impressions of sediment grains or resulting from biodegradation (plate 2a). The 'wall' of the compressed carbonaceous spheres of Chuaria is represented by a massive layer (plate 2b). At places small folds are randomly distributed on the wall surface (plate 2c). Irregular cavities are found in particular regions of the massive layer ('wall') in some specimens (plate 2d). Amard (1992) found that the wall exhibits a stepped row of horizontal dark and light lamellae and in some cases a column-like structure with perforations communicates between the lamellae and concluded that a number of lamellae are variable from one specimen to another depending on biological factors like juvenile or mature stage. Such structures have not yet been identified in the SEM images of Chuaria from the Suket Shale of Rampura; and these structures have not been found in the specimens from the Chuar Group (Jux 1977), Liulaobei Formation (Steiner 1994) or the Visingsö Group (Steiner 1994; Talyzina 2000). According to SEM studies, the internal wall construction of Chuaria from the Suket Shale seems to be single layered (plate $2 \mathrm{~b}$ ). The cavities within the solid organic body are observed in some specimens (plate $2 \mathrm{~d}$ ). These cavities were either formed by dissolution of sediment, which had been incorporated within the wall before fossilization or by biodegradation.

The 'zonal dark lamellae' of the topotype C. circularis reported by Jux (1977) using TEM and compared to those of Devonian Tasmanites and
Tapajonites (Jux 1977), are not comparable to the structures in Chuaria of the Suket Shales. Microtome sections in the present study show lamellar structures (plate 2e and 2f). However, it is likely that these lamellar structures have formed during the sectioning process. Similar sectioning artifacts have also recently been described from organic microfossils of the Mesoproterozoic Roper Group of Australia (Javaux et al 2004; figures 3j, k). Jux (1977) observed in TEM ultrasections of Chuaria a "fine network of trabecular ultrastructure of the wall" at very high magnification. This ultrafine structure (the mesh of which is of the order of $0.001 \mu \mathrm{m}$ ) is regarded by him as a fundamental feature of the topotype $C$. circularis. Amard (1992) also reported radial canals comparable to those reported by Jux (1977), but such ultrastructure has not been recorded in TEM ultrasections of Chuaria from the Suket Shale and also not been reported from the Cryogenian sequence of Australia (Arouri et al 2000). The SEM and TEM studies of specimens from the Liulaobei Formation in China (Steiner 1994) did not reveal any canal structures. Talyzina (2000) compared few cavities within the 'wall' of Chuaria from the Visingsö Formation with 'radial canal' structures reported by Jux (1977) and Amard (1992). The herein observed irregular cavities (plate 2f) occur only locally, probably caused by degradation. However, they are different from the cavities reported by Talyzina (2000) from Chuaria of the Visingsö Formation. TEM sections of leiosphaerids, which may be related to translucent specimens of Chuaria circularis, showed a similar ultrastructural construction as in Chuaria (Steiner 1994; Javaux et al 2004). Porous inner zones of a compact layer may represent preservational artifacts which may be due to later degradation (compare Steiner 1994; Javaux et al 2004). The interpretation of a fine-layered construction of wall in leiosphaerids and the existence of a trilaminar structure may also be due to preservational artifacts (see Javaux et al 2004).

\section{Reflectance studies}

A determination of thermal maturity of preSilurian sedimentary rocks from a routine application of petrographic techniques is somewhat limited due to the absence of higher plant material. Incident light microscopy studies of marine fossils (e.g., chitinozoa, graptolites and scolecodonts) which are very common in Lower Paleozoic sedimentary rocks have been used for maturity studies in the last two decades (Bertrand and Héroux 1987; Hoffknecht 1991; Obermajer et al 1996). But no initiative has been made until today for maturation studies of Precambrian sediments using 
(a)

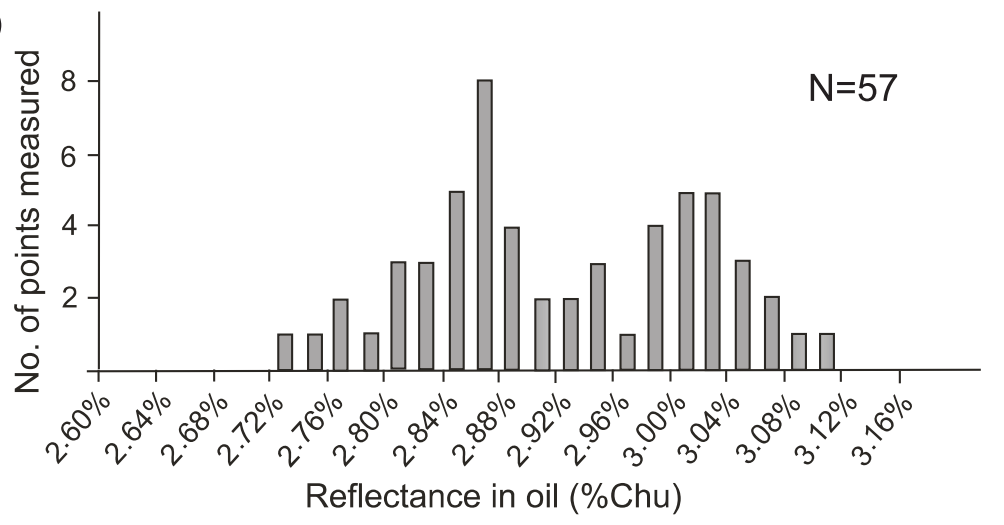

(b)

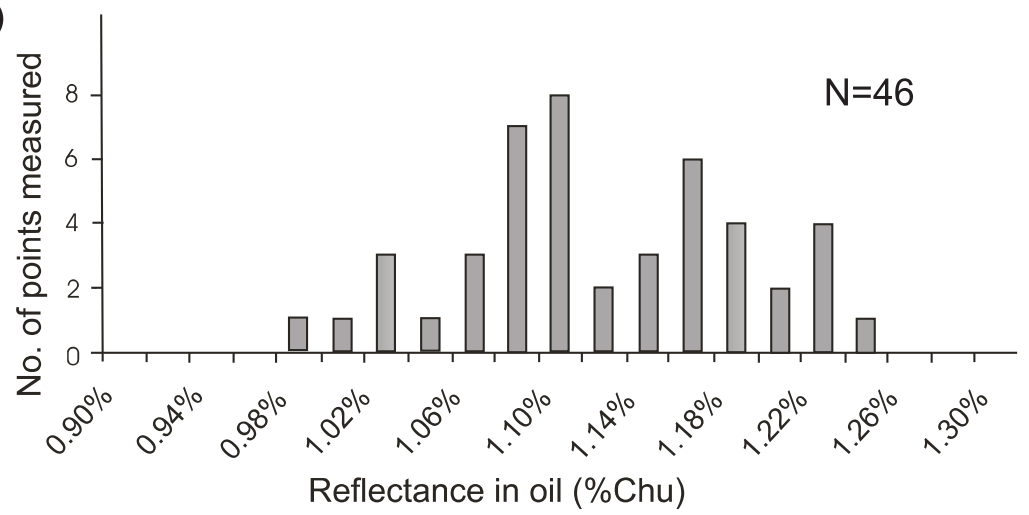

(c)

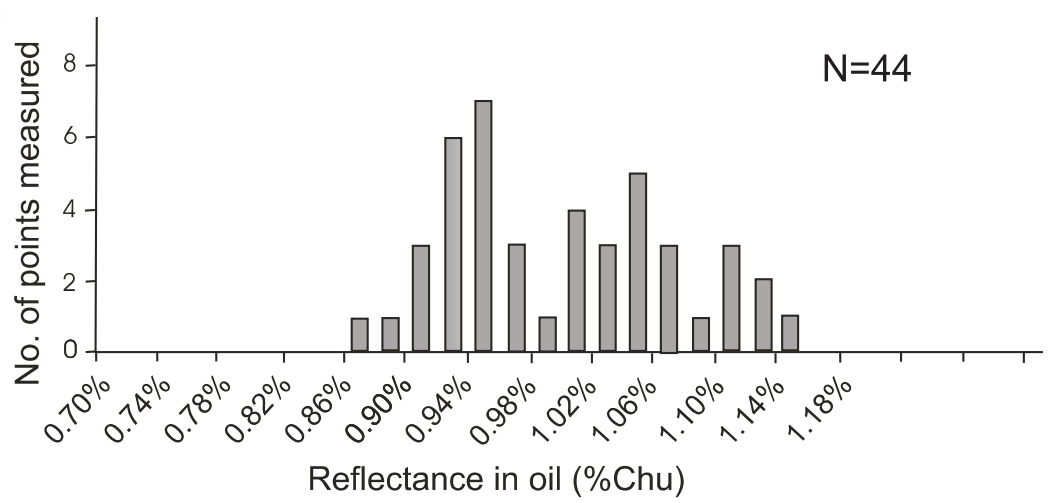

Figure 5. Composite histograms showing distribution of reflectance of Chuaria from (a) the Suket Shale, India (sample number Ram 216); (b) the Visingsö Formation. Sweden (sample number Mul 1); (c) the Liulaobei Formation, China (sample number Llb 339b).

reflectance studies of Chuaria. In the present study the reflectance of Chuaria was investigated as a means of determining the level of thermal maturity. Altogether 10 samples of Chuaria were measured from the Suket Shale. For comparison, Chuaria from the Visingsö Formation (Sweden) and from the Lilulaobei Formation (China) were also measured. The histograms of the reflectance studies of different samples are given in figure $5(\mathrm{a}-\mathrm{c})$. The maximum value of reflectance of Chuaria $\left(\mathrm{ChuR}_{0}\right)$ from the Suket Shale is $3.20 \%$ and the lowest value is $2.16 \%$. The median values of $\mathrm{ChuR}_{0}$ ranges from $2.34 \%$ to $2.90 \%$. Reflectance of Chuaria from the Visingsö Formation ranges from 1.1 to $1.24 \%$ (figure $5 \mathrm{~b}$ ) and from $0.86 \%$ to $1.14 \%$ in the Lilulaobei Formation (figure 5c). Chuaria from different formations shows different values of reflectance, which, in turn, probably indicates differences in their thermal maturity. The carbonaceous fossils from the Suket Shale show the highest maturity while that of the Liulaobei Formation is lowest and those of the Visingsö Formation are intermediate. Indian Chuaria samples and its host sediments have experienced a comparably high thermal overprinting as reflected from other black shale horizons of the Vindhyan basin which are overmatured (see Banerjee et al, this volume). Thermal maturity of organic remains depends on several factors 


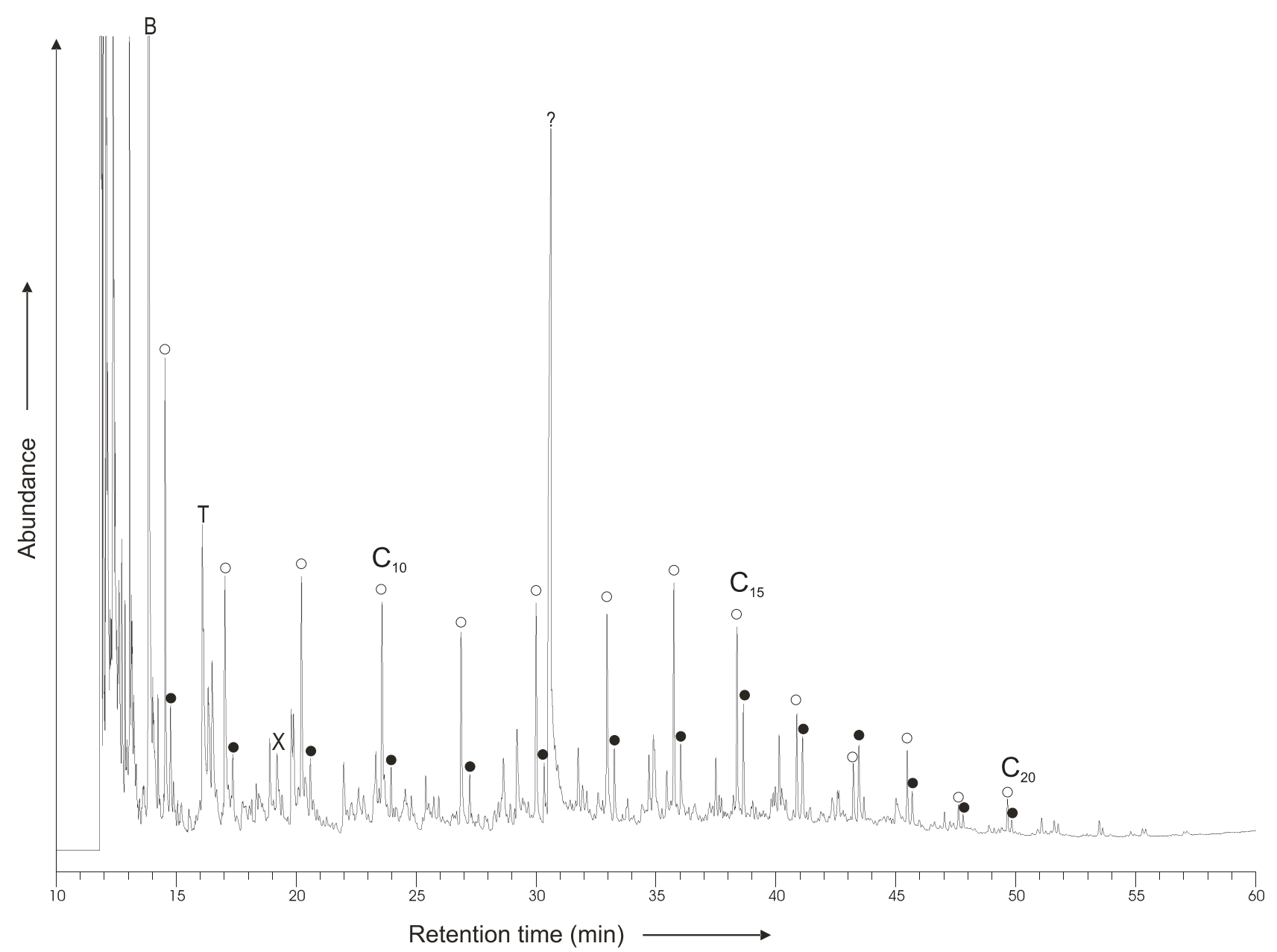

Figure 6. Total ion chromatogram resulting from Pyrolysis-GC of Chuaria circularis, Suket Shale, Vindhyan Supergroup, India. Each doublet corresponds to an alkene $(\circ)$ and an alkane $(\bullet)$; selected C-numbers indicated. B, T and X indicate benzene, toluene and ethyl benzene, respectively.

during sedimentary basin evolution (Poelchau et al 1997; Yalçin et al 1997) and an analytical compilation of all these factors are beyond the scope of this paper. Here it is just concluded that reflectance studies of Chuaria might represent a time-temperature scale and tool to compare maturity of Precambrian sediments.

\section{Molecular composition}

The total ion chromatogram obtained by Pyrolysis-GC of the Chuaria from the Suket Shale is shown in figure 6 . The pyrolysates are dominated by a bimodal distribution of $n$-alkene/ $n$-alkane doublets ranging from $\mathrm{C}_{7}$ to $\mathrm{C}_{22}$ with maxima at $\mathrm{C}_{7}$. $n$-alkene $/ n$-alkane doublets are typical products of the algaenan biopolymer which occurs in the cell walls of various marine and fresh water algae (Hatcher and Clifford 1997). Aromatic compounds like benzene, toluene, ethylbenzene have been detected. Pyrolytic studies of Chuaria from the Australian Centralian Superbasin were carried out by Arouri et al (2000), however, no GC-amenable pyrolysates were produced and thus it was concluded by these authors that the samples were highly overmature. A similar pattern is also reflected by the present pyrolytic studies of Chuaria as abundance of pyrolysates of this organic walled fossil is very low. But, any molecular investigation of this enigmatic fossil is essential to increase knowledge on its biological affinity. Pyrolytic degradation techniques for Precambrian kerogen are well known, but separation of indigenous molecular fossils from contaminants is sometimes difficult (see Brocks et al 2003). Prior to chemical investigation, the Chuaria samples were cleaned several times by dichloromethane, which minimizes the probability of the presence of any contaminant. Recently, Grice et al (2003) carried out Curie point pyrolysis of the fresh water alga Botryococous braunii from Miocene/Pliocene age and found a homologous series of $n$-alkene/n-alkane doublets. Similarly, 


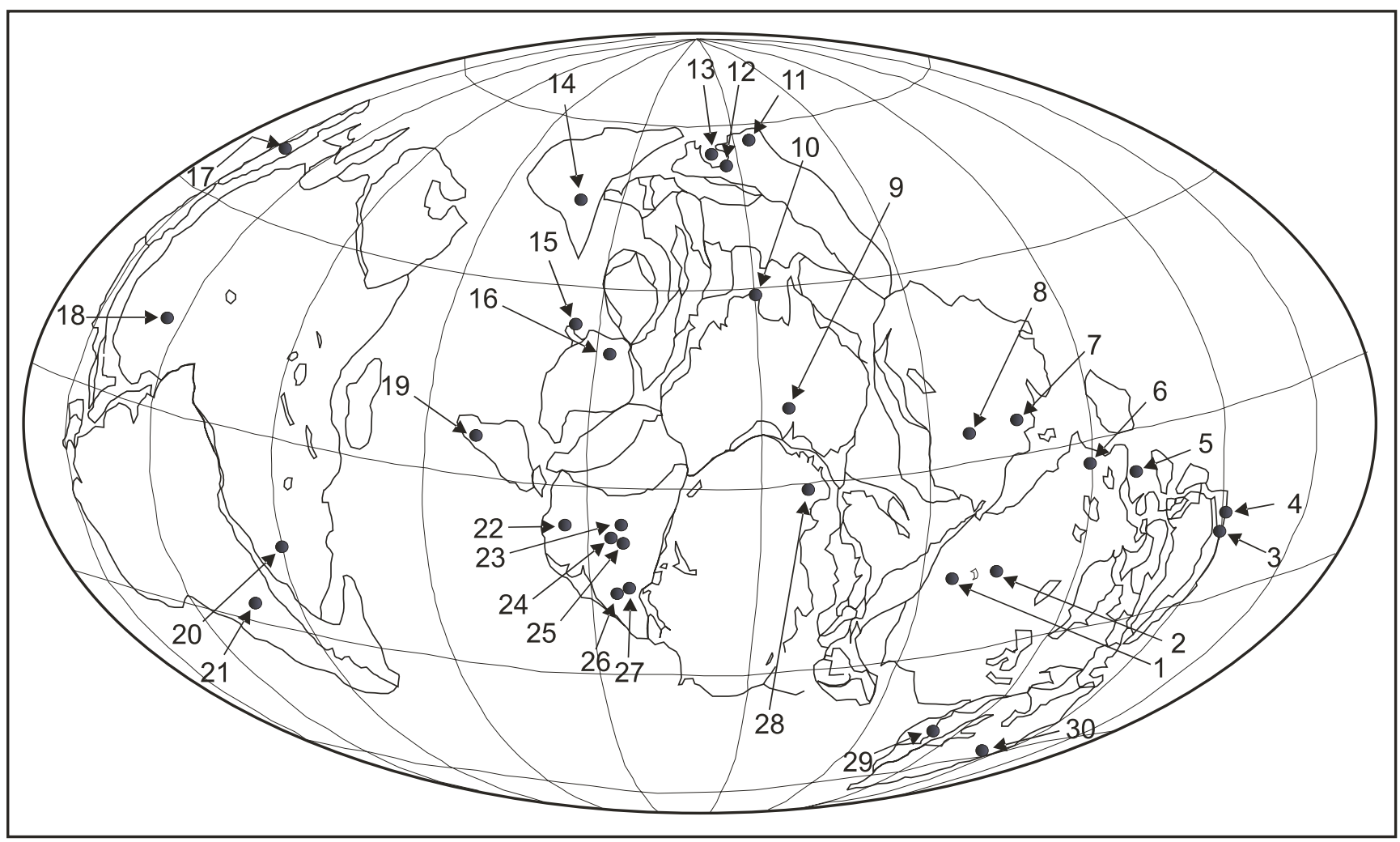

Figure 7. Distribution of the Chuaria circularis in a palaeogeographic reconstruction of Vendian age (Paleogeographic reconstruction modified after Kirschvink 1992). (1) Chuar Group, USA (Ford and Breed 1973); (2) Uinta Mountain Group, Utah, USA (Hofmann 1977); (3) Franklinsundet Group Kapp Lord Formation, Spitsbergen (Knoll 1982); (4) Akademikerbreen Group, Svanbergfjellet Formation, Spitsbergen (Butterfield et al 1994); (5) Shaler Supergroup, Wynniatt Formation, Victoria Island, Canada (Hofmann and Rainbird 1994); (6) Little Dal Group, Mackenzie Mountain, Canada (Hofmann 1985b); (7) Debengdin, Khajpakh and Khatyspyt Formations, Yakutia (Vidal et al 1993); (8) Lachandin Formation, UchurMaja, Siberia (Pjatiletov 1980); (9) Tent Hill Formation, Arcoona Quartzite, South Australia (Damssa and Knoll 1986); (10) Wessel Group, Raiwalla Shale, Maningrida, Australia (Haines 1998); (11) Liulaobei and Jiuliqiao Formations, Shouxian, China (Sun 1987); (12) Changlongshan Formation, Xinglong and Huailai, Hebei, China (Du and Tian 1985); (13) Guotun, Diaoyutai, Nanfeng Formations, S. Liaoning, China (Chen 1991); (14) Chichkan Series, Mali karatau, Kazakhstan (Ogurtsova and Sergeev 1989); (15) Shilu Group, Hainan Island, China (Zhang et al 1991); (16) Qingshuigou Formation, China (Dai and Peng 1987); (17) Pusa Shale, Spain (Brasier et al 1979); (18) Pendjari Formation, Benin and Burkina-Faso, west Africa (Amard 1992); (19) Soltanieh Formation, Chapoghlu Shale, Elburz Mountain, Iran (Ford and Breed 1973); (20) Nama Group, Namibia (Germs et al 1986); (21) Sierra Bayas Formation, Argentina (Baldis et al 1983); (22) Vindhyan Supergroup, Suket Shale, Rampura, India (Sahni 1977; Kumar 2001); (23) Vindhyan Supergroup, Rewa Formation, Jhiri Shale, India (Rai et al 1997); (24) Vindhyan Supergroup, Bhander Limestone and Sirbu Shale, Maihar, India (Kumar and Srivastava 1997); (25) Vindhyan Supergroup, Rohtas Formation, Katni, India (Rai and Gautam 1998); (26) Bhima Group, Gangurthi Shale, south India (Suresh and Sundara Raju 1983); (27) Kurnool Group, Owk Shale, Andhra Pradesh, India (Sharma and Shukla 1999); (28) Robertson Bay Group, Northern Victoria Land, Antarctica (Cooper et al 1982); (29) Visingsö Group, Sweden (Vidal 1974); (30) Kanilov Formation, Podolia, Ukrain (Steiner 1997).

pyrolysis of the marine alga Tasmanites from the Permian revealed $n$-alkene $/ n$-alkane doublets with tricyclic hydrocarbons (Greenwood et al 2000). Benzenes and alkylbenzenes were other pyrolysates detected in the pyrolysates. Low relative abundances of these aromatic compounds are also a common feature of algaenan (e.g., Derenne et al 1992). The alkylated aromatic products probably derive from biological precursors although pyrolysis-induced aromatisation processes can contribute to the abundance of simple aromatic hydrocarbons (see Larter and Horsfield 1993). Li et al (2004) carried out pyrolysis of $1.2 \mathrm{Ga}$ kerogen from the Hongshuizhuang Formation, north China and found that the pyrolytic products consist of benzene and naphthalene and that their alkylated homologs and $n$-alyphatic products occur in subordinate amounts suggesting that this kerogen originated from Proterozoic cyanobacteria. A significant aliphatic moiety was detected from the Neoproterozoic acritarchs from south Australia and it was concluded that these acritarchs were Chlorophycean algae (Arouri et al 1999). Very recently, Dutta et al (2006) carried out pyrolysis of handpicked prasinophycean algae (e.g., Tasmanites, Leiosphaeridia) from the Dadas 
Formation, SE-Turkey and observed predominance of $n$-aliphatic products. It is true that migration of aliphatic moieties from matrix to fossil is a topic of considerable debate in the field of organic geochemistry (see Stankiewicz et al 2000; Versteegh et al 2004; de Leeuw et al in press). At the present state of our knowledge, the predominance of $n$-aliphatic pyrolysates of Chuaria are consistent with a highly aliphatic nature and thus provides hints towards an algal affinity. These organic remains were probably very early eukaryotic algae which appeared during Early Mesoproterozoic time in the area of Indian Platform.

\section{Age and geographical distribution}

Chuaria has a wide geographical distribution and is recorded from United States, Canada, Russia, Australia, China, Kazakhstan, Spain, Namibia, Benin, Iran, Argentina, India, Antarctica, Sweden and Moldova/Ukraine (figure 7). Ford and Breed (1973) considered Chuaria as a potential index fossil for the time range of $1000 \mathrm{Ma}$ to $570 \mathrm{Ma}$. But Hofmann and Chen (1981) and Du and Tian (1985) reported Chuaria from sedimentary sequences of Paleoproterozoic age. Recently, a Chuaria-Tawuia assemblage has also been found from the Paleoproterozoic Changzhougou Formation in the Yanshan Range, north China (Zhu et al 2000). Vidal et al (1993) discussed the significance of the time range of the Chuaria-Tawuia assemblage with emphasis on the 700-840 Ma interval, which generally predates the Varanger glacial event. A similar conclusion was also reached by Sun (1987) mentioning that Chuaria occurrences fall in the time range of 700-1000 Ma. However, Steiner (1994) reported Chuaria from the Early Cambrian (520-545 Ma) Yanjiahe Formation at Heziao and Jijiapo, Hubei Province, south China. Based on the discoveries of fossils in an underlying unit, Amard (1997) also suggested an Early Cambrian age for Chuaria from the Pendjari Formation of west Africa. Therefore, the presently recorded stratigraphic range of Chuaria circularis seems to range from the Paleoproterozoic to Early Cambrian. Accordingly, Chuaria circularis cannot be used as a biostratigraphic tool for global correlation of Proterozoic sedimentary sequences.

\section{Conclusions}

External surface features of C. circularis from the Suket Shale like wrinkles and 'opening structures' are of taphonomic origin. Colour and/or opacity are not useful to define the genus because they depend on the wall thickness of the fossil.
The investigated material of $C$. circularis from India shows neither radial pores nor canals like those which are typical of Tasmanites, nor trabecular ultrastructures as observed by TEM in the topotype material of $C$. circularis. The cavities within the fossil wall occur only locally, and have therefore resulted either from previously incorporated sediments or by degradation of the specific inner part of the fossil. The reflectance of $C$. circularis represents a useful tool for comparative maturity studies of Precambrian sediments. The gas chromatographic determination of pyrolysates from $C$. circularis suggests an eukaryotic algal affinity due to the predominance of $n$-alkane/ $n$-alkene doublets. Based on a review of the age and geographical distribution of $C$. circularis, it is concluded that $C$. circularis cannot be considered as an index fossil for the biostratigraphic subdivision of the Proterozoic.

\section{Acknowledgements}

The Deutscher Akademischer Austauschdienst (DAAD) is acknowledged for providing a scholarship to SD during his stay at the Technical University, Berlin. Mr. S Das (IIT Bombay) is gratefully acknowledged for his support with reflectance studies. We thank Mr. F Leistner for assistance with PY-GC and Mr. J Nissen and Mr. R Liedtke for support with electron microscopy. SB is thankful to the Department of Earth Sciences, IIT Bombay for infrastructural facilities. Authors are thankful to Dr. N Butterfield and Dr. M Sharma for useful reviews of the earlier version of the manuscript.

\section{References}

Amard B 1992 Ultrastructure of Chuaria (Walcott) Vidal and Ford (Acritarcha) from the Late Proterozoic Pendjari Formation, Benin and Burkina-Faso, West Africa; Precamb. Res. 57 121-133.

Amard B 1997 Chuaria pendjariensis n. sp. Acritarche $\mathrm{du}$ bassin des Volta, Benin et Burkina-Faso, Africa de l'Ouest: un taxon nouveau du Cambrien inférieur; C. R. Acad. Sci. Paris T324 (série Iia) 477-483.

Arouri K R, Greenwood P F and Walter M R 1999 A possible chlorophycean affinity of some Neoproterozoic acritarchs; Org. Geochem. 30 1323-1337.

Arouri K R, Greenwood P F and Walter M R 2000 Biological affinities of Neoproterozoic acritarchs from Australia: microscopic and chemical characterization; Org. Geochem. 31 75-89.

Baldis E D P, Baldis B A and Cuomo J 1983 Los fosiles Precambricos de la formacion Sierras Bayas (Olavarria) y su importancia intercontinental; Asociación Geológica Argentina, Revista XXXVII (1) 73-83.

Banerjee S, Dutta S, Paikaray S and Mann U 2006 Stratigraphy, sedimentology and bulk organic geochemistry of black shales from the Proterozoic Vindhyan Supergroup (central India); J. Earth Syst. Sci., this issue. 
Bertrand R and Héroux 1987 Chitinozoan, Graptolite and Scolecodont reflectance as an alternative to vitrinite and Pyrobitumen reflectance in Ordovician and Silurian strata, Anticosti island, Quebec, Canada; AAPG Bulletin 71 951-957.

Bose P K, Sarkar S, Chakraborty S and Banerjee S 2001 Overview of the Meso- to Neoproterozoic evolution of the Vindhyan basin, Central India; Sedim. Geol. 141 395-419.

Brasier M D, Parejon A and De San Jose M A 1979 Discovery of an important fossiliferous Precambrian-Cambrian sequence in Spain; Estudios Geol. 35 379-383.

Brocks J J, Love G D, Snape C E, Logan G A, Summons R E and Buick R 2003 Release of bound aromatic hydrocarbons from late Archean and Mesoproterozoic kerogens via hydropyrolysis; Geochimica et Cosmochimica Acta 67 1521-1530.

Butterfield N J, Knoll A H and Swett K 1994 Paleobiology of the Neoproterozoic Svanbergfjellet Formation, Spitsbergen; Fossils and Strata 34 1-84.

Chanda S K and Bhattacharyya A 1982 Vindhyan sedimentation and paleogeography: post-Auden developments; In: Geology of Vindhyanchal (eds) Valdiya K S, Bhatia S B and Gaur V K (New Delhi: Hindustan Publishing Corporation) pp. 88-101.

Chapman F 1935 Primitive fossils, possibly Atrematous and Neotrematous brachiopoda from the Vindhyans of India; Rec. Geol. Surv. Ind. 69 109-120.

Chen M 1991 Discussion on the stratigraphic significance of macrofossils from the Late Precambrian sequence in Southern Liaoning Province; Scienta Geologica Sinica 2 120-128.

Cooper R A, Jago J B, Mackinnon D I, Shergold J H and Vidal G 1982 Late Precambrian and Cambrian fossils from Northern Victoria Land and their stratigraphic implications; In: Antarctic Geoscience (ed.) Craddock C (The University of Wisconsin Press) pp. 629-633.

Dai H and Peng Y 1987 Stratigraphic classification and biota characters of Late Presinian in Yunnan and discussion on its ages; Precambrian Geology (Beijing: Geological Publishing House) pp. 115-126.

Damassa S P and Knoll A H 1986 Micropalaeontology of the late Proterozoic Arcoona Quartzite Member of the Tent Hill Formation, Stuart Shelf, South Australia; Acheringa 10 417-430.

de Leeuw J W, Versteegh G J M and van Bergen P F Biomacromolecules of algae and plants and their fossil analogues; Plant Ecology. (in press).

Derenne S, Largeau C, Berkaloff C, Rousseau B, Wilheim C and Hatcher P 1992 Non-hydrolysable macro-molecular constituents from outer walls of Chlorella fusca and Nanochlorum eucaryotum; Phytochemistry $\mathbf{3 1}$ 1923-1929.

Du R and Tian L 1985 Algal macrofossils from the Qingbeikou System in the Yanshan Range of North China; Precamb. Res. 29 5-14.

Duan C 1982 Late Precambrian algal megafossils Chuaria and Tawuia in some areas of eastern China; Alchering 6 $57-68$.

Dutta S, Greenwood P F, Brocke R, Schaefer R G and Mann U 2006 New insights into the relationship between Tasmanites and tricyclic terpenoids; Organic Geochemistry 37 117-127.

Eisenack A 1966 Über Chuaria wimani Brotzen; Neues Jahrbuch für Geologie und Paläontologie 1 52-56.

Ford T D and Breed W J 1973 The problematical Precambrian fossil Chuaria; Palaeontology 16 $535-550$
Germs G J B, Knoll A H and Vidal G 1986 Latest Proterozoic microfossils from the Nama Group, Namibia (South West Africa); Precamb. Res. 32 45-62.

Ghare M A and Badve R M 1978 On Chuaria circularis Walcott from the Suket Shale of Rampura, Madhaya Pradesh; In: Proceedings of the Seventh Indian Colloq. on Micropalaeontology and Stratigraphy (ed.) Rasheed D A (University of Madras, Madras) pp. 31-40.

Greenwood P F, Arouri K R and George S C 2000 Tricyclic terpenoid composition of Tasmanites kerogen as determined by pyrolysis GC-MS; Geochim. Cosmochim. Acta 64 1249-1263.

Grice K, Schouten S, Blokker P, Derenne S, Largeau C, Nissenbaum A and Sinninghe Damsté J S 2003 Structural and isotopic analysis of kerogens in sediments rich in free sulfurised Botryococcus braunii biomarkers; Org. Geochem. 34 471-482.

Hatcher P G and Clifford D J 1997 The organic geochemistry of coal: from plant materials to coal; Org. Geochem. 27 251-274.

Haines P W 1998 Chuaria Walcott, 1899 in the lower Wessel Group, Arafura Basin, northern Australia; Alcheringa 22 1-8.

Hoffknecht A 1991 Mikropetrographische, organischgeochemische, mikrothermometrische und mineralogische Untersuchungen zur Bestimmung der organischen Reife von Graptolithen-Periderm; Göttinger Arbeiten zur Geologie und Paläontologie 48 1-98.

Hofmann H J 1971 Precambrian fossils, pseudofossils and problematica in Canada; Bull. Geol. Surv. Canada 189 $1-146$.

Hofmann H J 1977 The problematic fossil Chuaria from the Late Precambrian Uinta mountain Group, Utah; Precamb. Res. 4 1-11.

Hofmann H J 1985a Precambrian carbonaceous megafossils; In: Paleoalgology: Contemporary Research and Applications (eds) Toomy D F and Nitecki M H (Berlin, Heidelberg: Springer-Verlag) pp. 20-33.

Hofmann H J 1985b The mid-Proterozoic Little Dal macrobiota, Mackenzie Mountains, northwest Canada; Palaeontology 28 331-354.

Hofmann H J 1992 Proterozoic carbonaceous films; In: The Proterozoic Biosphere - A Multidisciplinary Study (eds) Schopf J W and Klein C (Cambridge: Cambridge University Press) pp. 349-357.

Hofmann H J and Chen J 1981 Carbonaceous megafossils from the Precambrian (1800 Ma) near Jixian Northern China; Can. J. Earth Sci. 18 443-447.

Hofmann H J and Rainbird R H 1994 Carbonaceous megafossils from the Neoproterozoic Shaler Supergroup of Arctic Canada; Palaeontology 37 721-731.

Javaux E J, Knoll A H and Walter M 2004 TEM evidence for eukaryotic diversity in mid-Proterozoic oceans; Geobiology 2 121-132.

Jones H J 1909 In: General Report, Rec. Geol. Surv. India 366.

Jux U 1977 Über die Wandstrukuren sphaeromorpher Acritarchen: Tasmanites Newton, Tapajonites Sommer and Van Boekel, Chuaria Walcott; Palaeontographica Abt. B 160 1-16.

Kirschvink J L 1992 A Paleogeographic model for Vendian and Cambrian time; In: The Proterozoic Biosphere (eds) Schopf J W and Klein C (Cambridge: Cambridge University Press) pp. 569-581.

Knoll A H 1982 Microfossil-based biostratigraphy of the Precambrian Hecla Hoek sequence, Nordaustlandet, Svalbard; Geol. Mag. 119 269-279.

Kumar S 2001 Mesoproterozoic megafossil Chuaria-Tawuia association may represent parts of a multicellular plant, 
Vindhyan Supergroup, Central India; Precamb. Res. 106 187-211.

Kumar S and Srivastava P 1997 A note on the carbonaceous megafossils from the Neoproterozoic Bhander Group, Maihar area, Madhya Pradesh; J. Pal. Soc. India 42 141-146.

Larter S R and Horsfield B 1993 Determination of structural components of kerogens by the use of analytical pyrolysis methods; In: Organic Geochemistry (eds) Engel M H, Macko S A (New York: Plenum Press) pp. 271-288.

Li C, Peng P, Sheng G and Fu J 2004 A study of a 1.2 Ga kerogen using $\mathrm{Ru}$ ion-catalyzed oxidation and pyrolysis-gas chromatography-mass spectrometry: structural features and possible source; Org. Geochem. 35 $531-541$

Mackowsky M T 1982 Methods and tools of examination; In: Textbook of Coal Petrology (eds) Stach E, Mackowsky M T, Taylor G H, Chandra D and Teichmüller R (Berlin: Gebrüder Borntraeger) pp. 295-299.

Maithy P K and Shukla M 1977 Microbiota from the Suket Shale, Rampura, Vindhyan System, Madhya Pradesh; Palaeobotanist 23 176-188.

Maithy P K and Shukla M 1984 Reappraisal of Fermoria and allied remains from the Suket Shale Formation, Rampura; Palaeobotanist 32 146-152.

Obermajer M, Fowler M G, Goodarzi F and Snowdon L R 1996 Assessing thermal maturity of Paleozoic rocks from reflectance of chitinozoa as constrained by geochemical indicators: an example from southern Ontario, Canada; Mar. Petrol. Geol. 13 907-919.

Ogurtsova R N and Sergeev V N 1989 The Megasphaeromorphids of the Tsitskaisk deposits of the Upper Precambrian of South Kazakhstan; Paleontologitscheskii J. 2 119-122 (in Russian).

Pjatiletov V G 1980 New finds of microfossils of Navifusa in the Lachandin stage; Palaeontologitscheskii J. 3 143-145.

Poelchau H S, Baker D R, Hantchel T, Horsfield B and Wygrala 1997 Basin simulation and the design of the conceptual basin model; In: Petroleum and Basin Evolution (eds) D H Welte, B Horsfield and D R Baker (Berlin, Heidelberg: Springer-Verlag) pp. 3-62.

Rai V and Gautam R 1998 New occurrence of carbonaceous megafossils from the Meso- to Neoproterozoic horizons of the Vindhyan Supergroup, Kaimur-Katni areas, Madhya Pradesh, India; Geophytology 26 13-25.

Rai V, Shukla M and Gautam R 1997 Discovery of carbonaceous megafossils (Chuaria-Tawuia assemblage) from the Neoproterozoic Vindhyan succession (Rewa Group), Allahabad-Rewa area, India; Curr. Sci. 73 783-788.

Rasmussen B, Bose P K, Sarkar S, Banerjee S, Fletcher I R and McNaughton N J $20021.6 \mathrm{Ga}$ U-Pb zircon ages for the chorhat sandstone, Lower Vindhyan: possible implications for the early evolution of animals; Geology $\mathbf{3 0}$ 103-106.

Sahni M R 1936 Fermeria minima: A revised classification of the organic remains from the Vindhyan of India; M. Rec. Geol. Surv. India 458-468.

Sahni M R 1977 Vindhyan palaeobiology, stratigraphy and depositional environments: a critical review; J. Pal. Soc. India 20 289-304.

Sarangi S, Gopalan K and Kumar S $2004 \mathrm{~Pb}-\mathrm{Pb}$ age of earliest megascopic, eukaryotic alga bearing Rohtas Formation, Vindhyan Supergroup, India: implications for Precambrian atmospheric oxygen evolution; Precamb. Res. 132 107-121.
Sarkar S, Banerjee S, Chakraborty S and Bose P K 2002 Shelf storm flow dynamics: insight from the Mesoproterozoic Rampur Shale, Central India; Sedim. Geol. 147 89-104.

Sharma M and Shukla M 1999 Carbonaceous megaremains from the Neoproterozoic Owk Shales Formations of the Kurnool Group. Andhra Pradesh, India; Curr. Sci. 76 1247-1251.

Stankiewicz B A, Briggs D E G , Michels R, Collinson M E, Flannery M B and Evershed R P 2000 Alternative origin of aliphatic polymer in kerogen; Geology $\mathbf{2 8}$ 559-562.

Steiner M 1994 Die Neoproterozoischen Megaalgen Südchinas; Berliner Geowissenschaftliche Abhandlungen (E) 15 1-146.

Steiner M 1997 Chuaria circularis WALCOTT 1899"Megasphaeromorph Acritarch" or Prokaryotic Colony? In: C. I. M. P. Acritarch in Praha (eds) Fatka $\mathrm{O}$ and Servais T; Acta Univ. Carolinae Geol. 40 645-665.

Sun W 1987 Palaeontology and biostratigraphy of Late Precambrian macroscopic colonial algae: Chuaria and Tawuia Hofmann; Palaeontographica Abt. B 203 109-134.

Suresh R and Sundara Raju T P 1983 Problematic Chuaria, from the Bhima Basin, South India; Precamb. Res. 23 79-85.

Talyzina M N 2000 Ultrastructure and morphology of Chuaria circularis (Walcott 1899) Vidal and Ford (1985) from the Neoproterozoic Visingsö Group, Sweden; Precamb. Res. 102 123-134.

Versteegh G J M, Blokker P, Wood G, Collinson M E, Sinninghe Damsté J S and de Leeuw J W 2004 Oxidative polymerization of unsaturated fatty acids as a preservation pathway for microalgal organic matter; Org. Geochem. 35 1129-1139.

Vidal G 1974 Late Precambrian microfossils from the basal sandstone unit of the Visingsö Beds, South Sweden; Geologica et Paleontologica 8 1-14.

Vidal G 1976 Late Precambrian microfossils from the Visingsö Beds in Southern Sweden; Fossil and Strata 9 $1-57$.

Vidal G, Moczydlowska M and Rudavskaya V A 1993 Biostratigraphical implications of a Chuaria-Tawuia assemblage and associated acritarchs from the Neoproterozoic of Yakutia; Palaeontology 36 387-402.

Walcott C D 1899 Precambrian fossiliferous formations; Geol. Soc. Am. Bull. 19 199-244.

White D 1928 Study of the fossil floras in the Grand Canyon; Carnegie Inst. Washington, Yearbook 27 389-390.

Yalçin M N, Littke R and Sachsenhofer R F 1997 Thermal history of sedimentary basins; In: Petroleum and Basin Evolution (eds) Welte D H, Horsfield B and Baker D R (Berlin, Heidelberg: Springer-Verlag) pp. 71-161.

Yuan X, Xiao S, Li J, Yin L and Cao R 2001 Pyritized chuaridis with excystment structures from the late Neoproterozoic Lantian formation in Anhui, South China; Precamb. Res. 107 253-263.

Zhang R, Feng S, MA G, XU G, Yan D, Li Z, Jiang D and WU W 1991 Discovery of Chuaria-Tawuia assemblage in Shilu Group, Hainan Island and its significance; Science in China (Series B) 33 211-222.

Zhu S, Sun S, Huang X, HE Y, Zhu G, Sun L and Zhang K 2000 Discovery of carbonaceous compressions and their multicellur tissues from the Changzhougou Formation (1800 Ma) in the Yanshan range, North China; Chinese Science Bulletin 45 841-847. 